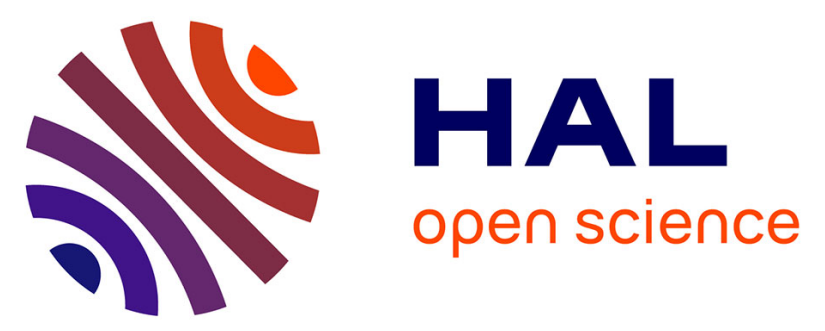

\title{
A history of chronic morphine exposure during adolescence increases despair-like behaviour and strain-dependently promotes sociability in abstinent adult mice

\author{
P.E. Lutz, D. Reiss, A.M. Ouagazzal, B.L. Kieffer
}

\section{To cite this version:}

P.E. Lutz, D. Reiss, A.M. Ouagazzal, B.L. Kieffer. A history of chronic morphine exposure during adolescence increases despair-like behaviour and strain-dependently promotes sociability in abstinent adult mice. Behavioural Brain Research, 2013, 243, pp.44-52. 10.1016/j.bbr.2012.12.049 . hal02437986

\section{HAL Id: hal-02437986 \\ https://hal.science/hal-02437986}

Submitted on 14 Jan 2020

HAL is a multi-disciplinary open access archive for the deposit and dissemination of scientific research documents, whether they are published or not. The documents may come from teaching and research institutions in France or abroad, or from public or private research centers.
L'archive ouverte pluridisciplinaire $\mathbf{H A L}$, est destinée au dépôt et à la diffusion de documents scientifiques de niveau recherche, publiés ou non, émanant des établissements d'enseignement et de recherche français ou étrangers, des laboratoires publics ou privés. 


\title{
A history of chronic morphine exposure during adolescence increases despair-like behaviour and strain-dependently promotes sociability in abstinent adult mice
}

\author{
PE Lutz ${ }^{1}$, D Reiss ${ }^{2}$, AM Ouagazzal' ${ }^{2}$, and BL Kieffer ${ }^{2}$ \\ ${ }^{1}$ McGill Group for Suicide Studies, Douglas Mental Health University Institute, McGill University, \\ Montreal, QC, Canada \\ ${ }^{2}$ Institut de Génétique et de Biologie Moléculaire et Cellulaire (IGBMC), Centre National de \\ Recherche Scientifique/Institut National de la Santé et de la Recherche Médicale/Université de \\ Strasbourg, Illkirch-Graffenstaden, France
}

\begin{abstract}
A crucial issue in treating opiate addiction, a chronic relapsing disorder, is to maintain a drug-free abstinent state. Prolonged abstinence associates with mood disorders, strongly contributing to relapse. In particular, substance use disorders occurring during adolescence predispose to depression later in adulthood. Using our established mouse model of opiate abstinence, we characterized emotional consequences into adulthood of morphine exposure during adolescence. Our results indicate that morphine treatment in adolescent mice has no effect on anxiety-like behaviours in adult mice, after abstinence. In contrast, morphine treatment during adolescence increases behavioural despair in adult mice. We also show that morphine exposure straindependently enhances sociability in adult mice. Additional research will be required to understand where and how morphine acts during brain maturation to affect emotional and social behaviours into adulthood.
\end{abstract}

\section{Keywords}

Morphine; adolescence; abstinence; sociability; depression; anxiety

\section{Introduction}

Addiction, defined mainly by a loss of control over drug seeking and consumption [1], is a chronic relapsing disorder. A crucial issue in treating addiction is to maintain a drug-free abstinent state. Prolonged abstinence is characterized by a negative affective state [2] and retrospective epidemiological studies consistently show that substance use disorders, notably for opiates, strongly associate with mood disorders [3-6]. Accordingly, a history of opiate dependence confers a 50\% lifetime risk of depressive comorbidity [7]. Although recognized

(C) 2012 Elsevier B.V. All rights reserved.

Corresponding author: Pierre-Eric Lutz (pierreeric.lutz@gmail.com), Douglas Mental Health University Institute, Pavillon Franck B common, 6875, boulevard LaSalle, Montréal, QC - Canada H4H 1R3.

Conflicts of interest

All authors report no biomedical financial interest or potential conflicts of interest.

Publisher's Disclaimer: This is a PDF file of an unedited manuscript that has been accepted for publication. As a service to our customers we are providing this early version of the manuscript. The manuscript will undergo copyediting, typesetting, and review of the resulting proof before it is published in its final citable form. Please note that during the production process errors may be discovered which could affect the content, and all legal disclaimers that apply to the journal pertain. 
as a major contributor to relapse, even after decades of abstinence [8-11], depression has received little attention in preclinical models of opiate dependence. Rodent studies have shown that during prolonged withdrawal from chronic opiate treatment, i.e. abstinence, drug seeking is potentiated by drug-associated cues [12-14], while motivation toward natural reinforcers is disrupted [15-19]. Only a few studies explored emotional behaviours, showing that depressive-like behaviours emerge during opiate withdrawal, from 3-6 days [20, 21] up to 2-3 weeks in rat [22] and after 9 days in mouse [23]. We established a mouse model of opiate protracted withdrawal [24], in which depressive-like behaviours strengthen during extended abstinence. Following chronic exposure to escalating doses of morphine, a prototypical opiate, abstinent mice progressively exhibited increased despair-like behaviour and low sociability. Importantly, both deficits were reversed by chronic antidepressant treatment.

Adolescence, the transition from child- to adulthood, is a plastic and dynamic process that largely condition psychopathological risk over the lifespan [25-27], notably the emergence of mood disorders [28]. Adolescents frequently experience recreational properties of drugs of abuse [27] which, in some individuals, eventually leads to substance use disorders. Longitudinal studies reveal that substance use disorders occurring during adolescence predispose to depression later in adulthood [29-31]. In rodent models, a few studies have addressed effects of opiates in adolescent individuals. In self-administration paradigms, opiate reinforcement is increased for morphine in rats [32] and oxycodone in mice [33], while unchanged for heroin in rats [34]. Further, after a short (3 days) spontaneous withdrawal from chronic morphine treatment, adolescent mice showed decreased despairlike behaviour, while no such effect is found in adults [23]. These increased reinforcing and decreased withdrawal-induced aversive properties of opiates in adolescent rodents are coherent with increased drug initiation during this period in human $[35,36]$. To our knowledge, the effects of chronic opiate exposure during adolescence on emotional responses in the adult have not been addressed in mice so far.

In the present study, we used our mouse model to characterize emotional consequences of a morphine exposure during adolescence in adult mice. Adolescent mice received escalating morphine treatment during 6 days. After 4 weeks of abstinence, we assessed emotional-like behaviours in these mice that had become adults. We performed this analysis in three classically used inbred strains: C57BL/6JCrl (Bl6J, as in our previous work [24]), C57BL/ $6 \mathrm{NCrl}(\mathrm{Bl6N})$ and Balb/cByJCrl (Balb).

\section{Material and methods}

\subsection{Animals}

Postnatal day 21 (P21) male mice were obtained from Charles Rivers Laboratories (StGermainsur-l'Arbresle, France) and habituated to housing conditions (4 animals per cage; $12 \mathrm{~h}$ light/dark cycle; food and water available ad libitum) for 1 week. All experimental procedures were performed according to standard ethical guidelines (European Community Guidelines on the Care and Use of Laboratory Animals 86/609/EEC).

\subsection{Drugs}

Morphine sulfate (Francopia, Gentilly, France) was prepared in saline solution ( $0.9 \%$ sodium chloride) and injected at a volume of $10 \mathrm{ml} / \mathrm{kg}$.

\subsection{Experimental procedure}

Age of mice for morphine treatment was chosen based on previous studies (see [23] and [27] for a review) so that adolescent mice received morphine injections from P30 to P35. We 
used the same morphine regimen as in our previous study in adult [24]. Our laboratory has previously shown that this regimen induces a strong physical dependence [37], one of the diagnosis criteria for opiate addiction in human [38]. Mice were administered intraperitoneally (i.p.) twice daily with (i) escalating doses of morphine (20, 40, 60, 80, 100 $\mathrm{mg} / \mathrm{kg}, \mathrm{n}=12 /$ mouse strain) for 5 days, followed by a single $100 \mathrm{mg} / \mathrm{kg}$ injection on day 6 , or (ii) saline solution as a control ( $n=12 /$ mouse strain). Each housing cage contained only saline-treated or only morphine-treated mice. The animals were then maintained drug free for 4 weeks (see Fig. 1A for experimental timeline). As an index of general opiate effects, mice were weighed daily during chronic injections and after 10 days (P45) and 29 days (or 4 weeks, P64) of abstinence. Beginning at P64, when abstinent mice have become adult, emotional-like and social behaviours were evaluated every other day (except for open-field and social interactions) using classical paradigms in the following order (see below) [24, 39]. For further information on behavioural testing procedures, see http://www.ics-mci.fr/ service_neurobiology_behaviour_tests.html.

\subsection{Behavioural testing}

2.4.1 Light-Dark (LD)—The apparatus consisted of two identical boxes (20x20x14cm) interconnected with a dark tunnel $(5 \times 7 \times 10 \mathrm{~cm}$, Imetronic, Pessac, France) equipped with infrared sensors. The light compartment (white walls) was brightly illuminated (1900 lux) from the ceiling. Mice were placed in the dark compartment (black walls) and the latency to enter the lit compartment, as well as the time spent in each compartment, were recorded during $5 \mathrm{~min}$.

2.4.2 Open-field (OF)—Mice were placed during $30 \mathrm{~min}$ in $44 \times 44 \mathrm{~cm}$ open-field arenas (Panlab, Barcelona, Spain), fitted with infrared beams allowing automated locomotor activity measures (Actitrack, Barcelona, Spain). Arenas were indirectly lit at 150 lux. Distance and time spent in the centre were recorded as locomotor activity and anxiety measures. This exposition to the open-field also served as habituation to the environment of the social interaction test, performed on the following day.

2.4.3 Social interactions (SI)—Pairs of unfamiliar mice, from different home cages but of similar treatment condition and weight, were placed simultaneously for $10 \mathrm{~min}$ in the open-field arena, indirectly lit at 50 lux. Our previous work indicates that both prior habituation to the arena and dim lighting favour social interactions in poorly anxiogenic conditions [24]. Using an ethological keyboard, we measured the number of occurrences and the total duration of social interaction behaviours (sniffing, following and pawing contact).

2.4.4 Tail suspension (TS)-Mice were suspended by the tail $50 \mathrm{~cm}$ above the floor. Activity was automatically monitored during the last 4 min of the 6-minute test (MED associates Inc, St Albans, USA), as previously described [39], with a threshold defining immobility behaviour. Latency to the first immobilization was also noted.

2.4.5 Forced swim(FS)—Mice were placed for 6 min into a glass cylinder (height, 27 $\mathrm{cm}$; diameter, $18 \mathrm{~cm})$ filled with 3.5 liters of water $\left(23 \pm 1^{\circ} \mathrm{C}\right)$, and immobility time was recorded during the last $4 \mathrm{~min}$ [39] by direct observation using an ethological keyboard. Latency to the first immobilization was also noted.

2.4.6 Y-maze (YM)—Mice were individually placed in a Y-shaped apparatus consisting in three arms (placed at $120^{\circ}$ from each other), and allowed to move freely (continuous procedure) for 5 min under moderate lighting conditions (100 lux in the centre-most region). An arm entry was counted when the mouse had all four paws inside the arm. The sequence of successive entries into the three arms was scored for each mouse, and the Y-maze 
performance, i.e. the percentage of spontaneous alternation performance, was defined as the ratio of actual alternations to possible alternations (total arm entries -2$) \times 100$ [40, 41].

\subsection{Statistical analysis}

All data are expressed as mean \pm sem. Statistical analysis was performed using two-way analysis of variance (ANOVA) with strain and treatment as independent variables. For the weight analysis, we used a three-way mixed ANOVA, with strain and treatment as betweensubject factors and time as within-subject factor. When required multiple group comparisons were performed using Fischer's post-hoc analysis. Statistical significance was defined as $\mathrm{p}<0.05$.

\section{Results}

\subsection{Weight growth}

A growth spurt is a hallmark of adolescence in rodents, with a rapid increase in body weight during the first 5 weeks of life [27]. Accordingly, ANOVA revealed a significant main effect of time $[\mathrm{F}(7,455)=1408 ; \mathrm{p}<0.0001]$, confirming that mice progressively gained weight during the course of the study, from P30 to P64 (Fig. 1B). ANOVA also revealed significant main effects of strain $[F(2,65)=9.99 ; p=0.0002]$ and morphine treatment $[F(1,65)=49.5$; $\mathrm{p}<0.0001]$, but no interaction between these 2 factors $[\mathrm{F}(2,65)=0.78 ; \mathrm{p}=0.46]$. Post-hoc comparisons showed that morphine-treated mice show reduced body weight compared to saline controls between P31 and P35 (post-hoc; $\mathrm{p}<0.0001$ ). Balb mice showed decreased body weight, compared to B16J or B16N (post-hoc; P31-35, p<0.05) during the course of chronic injections.

During abstinence, while left drug-free in their home-cages, morphine-abstinent mice gained more weight than saline controls (time $x$ treatment interaction, $[F(7,43)=19.2 ; \mathrm{p}<0.0001]$ ). Thus, after 4 weeks of abstinence and prior to behavioural testing, morphine abstinent mice recovered body weight no longer different from saline controls (post-hoc; $\mathrm{P} 45, \mathrm{p}<0.0001$; $\mathrm{P} 64, \mathrm{p}=0.07)$.

\subsection{Light-dark}

Results for every behavioural test are summarized in Table 1. We first analysed the anxietylike behaviour of morphine- and saline-treated mice in the light dark test. Analysis of the percentage time spent in the aversive brightly lit compartment (Fig. 2A) revealed a significant main effect of strain $[\mathrm{F}(2,65)=5.6 ; \mathrm{p}=0.0056]$, but no effect of morphine treatment $[\mathrm{F}(1,65)=2.31 ; \mathrm{p}=0.13]$ and no interaction $[\mathrm{F}(2,65)=0.04 ; \mathrm{p}=0.96]$. Inter-strain comparisons showed that the B16N showed highest levels of anxiety, an effect significant against B16J mice ( $\mathrm{p}=0.0014)$ and very close to significance against Balb mice $(\mathrm{p}=0.051)$. We did not find any difference $(\mathrm{p}=0.20)$ between $\mathrm{B} 16 \mathrm{~J}$ and Balb mice in this test, coherent with previous results [42].

Accordingly, latency to first entry into the lit compartment (Fig. 2B) was significantly different across strains $[\mathrm{F}(2,65)=19 ; \mathrm{p}<0.0001]$. Morphine treatment had no effect on this parameter $[\mathrm{F}(1,65)=0.17 ; \mathrm{p}=0.68]$, and there was no interaction $[\mathrm{F}(2,65)=0.90 ; \mathrm{p}=0.41]$. Inter-strain comparisons indicated that latency was increased in B16N mice compared to both Balb $(\mathrm{p}<0.0001)$ and Bl6J mice $(\mathrm{p}<0.0001)$.

\subsection{Open-field}

We also measured the percentage time spent in the centre of the OF (Fig. 2C), an index of anxiety-like behaviour in rodents. We found a significant effect of strain $[\mathrm{F}(2,65)=4.42$; $\mathrm{p}=0.016]$, with no effect of treatment $[\mathrm{F}(2,65)=2.37 ; \mathrm{p}=0.13]$ and no interaction 
$[F(2,65)=0.02 ; p=0.98]$. Inter-strain comparisons indicated that Balb mice showed increased anxiety-like behaviour as compared to $\mathrm{B} 16 \mathrm{~J}(\mathrm{p}=0.007)$, in agreement with previous data [43, 44]. Balb mice were also more anxious than $\mathrm{B} 16 \mathrm{~N}(\mathrm{p}=0.02)$, while $\mathrm{B} 16 \mathrm{~J}$ and $\mathrm{B} 16 \mathrm{~N}$ strains did not differ $(\mathrm{p}=0.70)$, as already reported [45].

We also assessed locomotor activity, as measured by the distance travelled in the OF (Fig. 2D). Two-way ANOVA revealed a significant effect of strain $[\mathrm{F}(2,65)=5.81 ; \mathrm{p}=0.005]$, with no effect of morphine treatment $[\mathrm{F}(1,65)=1.46 ; \mathrm{p}=0.23]$ and no interaction $[\mathrm{F}(2,65)=1.78$; $\mathrm{p}=0.18]$. Coherent with results from other groups [44, 46], Balb mice exhibited lower locomotor activity as compared to B16J (post-hoc, $\mathrm{p}=0.001$ ) and $\mathrm{B} 16 \mathrm{~N}$ mice (post-hoc, $\mathrm{p}=0.04$ ). The 2 later strains showed similar locomotor activity (post-hoc, $\mathrm{p}=0.20$ ).

\subsection{Social interactions}

We assessed social interactions after 4 weeks of abstinence by measuring the duration and number of occurrences of social behaviours in the three mouse strains. ANOVA showed that strain had a significant effect on the time pairs of unfamiliar mice spent interacting (Fig. 3A) $[\mathrm{F}(2,29)=7.19 ; \mathrm{p}=0.003]$, with Balb mice showing lower levels of sociability compared to $\mathrm{B} 16 \mathrm{~N}(\mathrm{p}=0.026)$ and $\mathrm{B} 16 \mathrm{~J}(\mathrm{p}=0.0005)$ mice. In addition, morphine treatment had a significant effect on the duration of social behaviours $[\mathrm{F}(1,29)=4.58 ; \mathrm{p}=0.04]$, and there was a significant interaction between strain and treatment $[\mathrm{F}(2,29)=4.14 ; \mathrm{p}=0.026]$. Post-hoc comparisons showed that morphine abstinence strongly increased the duration of social behaviours in $\mathrm{B} 16 \mathrm{~N}(\mathrm{p}=0.031)$ and Balb $(\mathrm{p}=0.018)$ mice, but had no effect in $\mathrm{B} 16 \mathrm{~J}$ mice $(\mathrm{p}=0.28)$. In B16N and Balb mice, increased duration of social behaviours was not due to a general hyperactivity, as locomotor activity was not modified in morphine abstinent mice (see Fig. 2D).

We also counted the number of social behaviours (Fig. 3B). ANOVA revealed that, similar to the analysis of duration, strain had a significant effect $[\mathrm{F}(2,29)=7.2 ; \mathrm{p}=0.0028]$ on these behaviours. In addition, morphine treatment had a significant effect $[\mathrm{F}(1,29)=5.7 ; \mathrm{p}=0.024]$, while there was no interaction $[\mathrm{F}(2,29)=1.8 ; \mathrm{p}=0.18]$.

\subsection{Tail suspension (TS) \& forced swim (FS)}

We assessed the duration of immobility in the TS and FS tests, as indexes of despair-like behaviours. In both TS $[F(2,65)=6.44 ; p=0.003]$ and $F S[F(2,65)=4.3 ; p=0.018]$, we found a significant main effect of strain on duration of immobility (Fig. 4A \& 4C). Balb mice exhibited the higher levels of immobility, being significantly different from B16N ( $\mathrm{p}=0.011)$ and B16J ( $\mathrm{p}=0.019)$ in the FS test (Fig. 4C), and from B16N ( $\mathrm{p}=0.0008)$, but not Bl6J $(\mathrm{p}=0.17)$, in the TS test (Fig. 4A). Comparing B16J and B16N strains, we found that they show similar despair-like behaviour in the FS test $(\mathrm{p}=0.84)$, while immobility is decreased in $\mathrm{B} 16 \mathrm{~N}$ in the TS test $(\mathrm{p}=0.034)$.

Importantly, statistical analysis revealed that morphine abstinence significantly increased the time spent immobile in the FS test $[\mathrm{F}(2,65)=4.01 ; \mathrm{p}=0.049]$, an effect close to significance in the TS test $[F(2,65)=3.56 ; p=0.063]$. Since morphine had no effect on locomotion (see OF, in Fig. 2D), we interpret this increased immobility in abstinent animals as increased behavioural despair. We found no interaction between morphine and strain in both tests (TS, $[F(2,65)=0.40 ; p=0.67]$ and $F S,[F(2,65)=0.50 ; p=0.61])$, although visual inspection of the FS data suggest that increased despair-like behaviour in morphine abstinence mainly occurs in $\mathrm{B} 16 \mathrm{~N}$ mice.

We also measured latency to the first immobilisation (Fig. 4B \& 4D), another index of despair-like behaviour [39]. We found a significant effect of strain in the TS (Fig. 4B) $[F(2,65)=4.7 ; p=0.012]$ and in the FS (Fig. 4D) $[F(2,65)=21.9 ; p<0.0001]$ tests. Coherent 
with the strain effect on immobility duration, Balb mice showed faster immobilization than (i) B16J in FS ( $p<0.0001)$ and TS ( $\mathrm{p}=0.048)$, and (ii) B16N in FS ( $<<0.0001)$ and TS $(\mathrm{p}=0.003)$. B16N and B16J strains showed similar latencies in TS $(\mathrm{p}=0.17)$ and $\mathrm{FS}(\mathrm{p}=0.99)$ tests. ANOVA also revealed a significant effect of morphine treatment on latency to first immobilization in the $F S[F(1,65)=6.4 ; p=0.013]$, but not in the TS $[F(1,65)=0.19 ; p=0.67]$ tests. There was no interaction between the 2 factors $(\mathrm{TS},[\mathrm{F}(2,65)=1.0 ; \mathrm{p}=0.37]$ and $\mathrm{FS}$, $[\mathrm{F}(2,65)=0.7 ; \mathrm{p}=0.49])$, although the data suggest that decreased latency to immobilization mainly occurs in Balb mice.

\subsection{Y-maze}

Morphine abstinent mice were tested using the Y-Maze (Table 1) to assess spatial working memory [47]. ANOVA revealed a significant effect of strain $[\mathrm{F}(2,64)=4.71 ; \mathrm{p}=0.012]$, with no effect of morphine exposure $[\mathrm{F}(1,64)=0.26 ; \mathrm{p}=0.61]$ and no interaction $[\mathrm{F}(2,64)=0.63$; $\mathrm{p}=0.53]$. Balb mice showed decreased spontaneous alternation (SPA) as compared to Bl6J and $\mathrm{B} 16 \mathrm{~N}$ mice (post-hoc, $\mathrm{p}=0.007$ and $\mathrm{p}=0.013$ respectively). This was already reported for Bl6J mice [41].

\section{Discussion}

In human, adolescent substance use disorders associate with an increased risk for anxiety and depression throughout life [29-31]. In the present study we used our mouse model of opiate abstinence to assess effects of chronic morphine exposure during adolescence on emotional responses in the adult. This model only partially recapitulates the human condition as it is based on passive drug exposure. In this respect it will be important to examine long-term effects of morphine across adolescence and adulthood in rodent models involving voluntary drug intake.

Opiate addiction [48, 49], as well as anxiety and depressive disorders [50], are strongly determined by genetic factors. Inbred mouse strains allow studying these factors in preclinical models [51,52] and high inter-strain variability has been reported for opiate physical dependence [53, 54], locomotor sensitization [55] and reinforcement [55, 56]. Few studies, however, have explored opiate-induced emotional responses across different mice strains. Here, we compared three different mouse strains. We found that abstinence from chronic morphine treatment increases the expression of despair-like behaviours and modifies sociability. Further, we observed that these effects are better detected in B16N and Balb strains.

\section{Weight growth in adolescent mice is stopped during chronic morphine treatment}

We measured body weights during escalating morphine treatment and abstinence, as an index of general opiate effects. In our previous study [24], morphine treatment decreased body weight by about $10 \%$ in adult mice, while no weight change occurred in saline-treated controls. In this study, morphine prevented adolescent growth, which otherwise occurred in saline treated animals. This effect was transient and differences were no longer significant after 4 weeks of abstinence. Morphine was shown to regulate feeding behaviours and locomotor activity in adult mice [57]. These morphine activities may also operate in adolescent animals and contribute to the observed growth arrest in our study.

\section{Inbred mice strains show strong behavioural differences}

Following 4 weeks of abstinence, we assessed several behavioural measures of emotion-like responses in adult mice. First, our results reveal higher levels of anxiety in Bl6N compared to B16J in the LD, but not in the OF. To our knowledge, only one study has compared both strains in these 2 tests. Matsuo et al [58]) reported (i) in the OF, increased anxiety-like 
behaviour in B16N as compared to B16J mice and (ii) in the $\mathrm{LD}$, no difference between the 2 strains. Taken together, the results by Matsuo et al and our data suggest that B16N mice exhibit higher levels of anxiety-like behaviours than B16J across different paradigms, yet the detection of these subtle effects highly relies on experimental conditions. In the OF, Balb mice presented higher levels of anxiety compared to the 2 other strains. Taken together, results from the LD and OF indicate that the 2 tests, using different aversive stimuli, measure different constructs of anxiety-like behaviours [59-61].

We also found that adult Balb mice exhibit low sociability compared to B16N and B16J. Using a three-chambered apparatus, previous studies showed that Balb mice exhibit poor exploration of the compartment containing an encaged congener [62, 63]. Our results further indicate that direct physical interactions in freely moving animals are also lower in Balb mice.

Finally, we found that adult Balb mice show higher levels of despair-like behaviours compared to B16J and B16N in TS and FS tests. Previous studies comparing Balb and B16J mice failed to detect increased levels of behavioural despair in Balb mice in the FS [64], and found no change [65] or a small increase [66] in the TS. The detection of strain differences in these paradigms therefore likely relies on experimental conditions. Overall, these results show that we detected phenotypic variations in our experimental conditions across inbred mice strains, both coherent with and extending on previous findings.

\section{Chronic morphine treatment during adolescence does not affect anxiety-like responses and working memory in adulthood}

Epidemiological studies in human indicate that opiate addiction strongly associates with an increased lifetime risk for anxiety disorders [7]. Our results in mice however suggest that adolescent morphine exposure does not disrupt the expression of anxiety-related responses later in adulthood, at least in two behavioural paradigms (LD and OF tests). Previous studies in our laboratory reported no effect of opiate abstinence in the same tests of anxiety, following adult exposure to either morphine [24] or heroin (Lutz et al, unpublished). Available data from other groups have yielded variable results, and reported either increased $[67,68]$ or decreased $[67,69]$ anxiety-like behaviour. Altogether, effects of repeated opiate exposure on anxiety-like behaviours appear complex, and highly depend on the species, opiate doses, duration of withdrawal and behavioural measures. Therefore, the comorbidity between opiate addiction and anxiety remains difficult to address in rodent models.

Opiate dependence is also associated with deficits in working memory [70, 71]. We tested the effect of adolescent morphine treatment on the cognitive performance of adult animals in a task of spatial working memory. While previous reports indicate that opiate exposure acutely impairs rodents performance in similar maze tasks [72-75], our present results suggest that these effects do not persist during abstinence.

\section{Chronic morphine treatment during adolescence regulates social behaviours}

Intriguingly, we also observed that exposure to morphine in adolescent mice enhances social interactions in the adults. Numerous data document the crucial regulation of social behaviours by the mu opioid receptor, the molecular target of morphine [37], across various developmental stages and species. This receptor regulates early social bounds to parents or caregivers in mice [76], primates [77] and humans [78]. Later in life, social interactions with peers play an important adaptive role during adolescence [79], promoting both encounters with individuals outside the natal group and independence from this group. Interestingly, endogenous opioid peptides are released throughout the brain during social behaviours in adolescent rodents $[80,81]$, and the mu receptor tightly regulates social reward both in 
adolescent rats [82] and mice [83]. In addition, acute social isolation enhances social investigation upon retrieval of a familiar congener in adolescent mice (P25-45), an effect that increases with the duration of the isolation period [84]. Acute morphine treatment blocks this effect of social isolation, suggesting that morphine administration can substitute for social reinforcement. Altogether these data show that the opioid system plays a critical role in the developmental maturation of social functions. Here, we show that chronic morphine treatment in adolescent mice increases social behaviours in adulthood. Considering the phylogenetic conservation of behavioural hallmarks of adolescence, and their regulation by the opioid system, we hypothesize that repeated exposure to morphine in adolescent mice could sensitize neurological substrates responsible for the expression of social behaviours over the lifespan. Interestingly, Van den Berg et al showed that morphine treatment in adolescent rats [81], combined with social isolation, increases social interactions later in adulthood. Also, activation of the mu opioid receptor within the nucleus accumbens has been shown recently to promote social play [85] in adolescent rats. We may speculate that in adolescent mice, chronic morphine treatment potentiates rewarding properties of encounters with cage-mates through opioid-sensitive circuits, possibly within the nucleus accumbens. This effect may be long-lasting and account for increased sociability expressed at adult age. Interestingly, in the aforementioned model of social investigation following isolation [84], a higher sensitivity to morphine was found in adolescent Balb mice as compared to $\mathrm{Bl6J}$ mice, a result that parallels those from the present study, showing prosocial, long-term morphine effects in Balb but not in Bl6J mice. The implication in such long-term morphine effects of neuropeptides regulating social behaviours [86], and sensitive to exogenous mu receptor activation (such as oxytocin [87] and vasopression [88]) remains to be determined.

Together with our previous study [24], we show in Bl6J mice that morphine exposure during adulthood, but not during adolescence, decreases sociability after an abstinence period. Thus, in this mouse strain, activation of the mu opioid receptor at different developmental stages produces divergent long-term effects on sociability. In the future, unravelling similar ontogenic changes in the regulation of social behaviours may help explain how these behaviours fulfil different functions (peer relationships during adolescence or reproduction in adulthood, for example) across development.

\section{Chronic morphine treatment during adolescence enhances despair-like behaviours in adulthood}

Adolescent morphine treatment globally increased (across the 3 strains) the expression of despair-like behaviours at adult age, as revealed in the FS. This finding suggests that inbred mice strains may be used to model opiate misuse in human adolescents in relation to the lifetime risk of depression, and could help identify underlying molecular adaptations. In adult mice [24], abstinence from chronic morphine treatment also increased despair-like behaviour, although the effect was detected in the TS, but not in the FS, suggesting that the abstinence phenotype may differ across developmental ages, possibly through divergent opioid mechanisms. In adults, we showed that chronic morphine exposure impairs the serotonergic neurotransmission $[24,89]$. Future studies should explore whether morphine similarly affects serotonin neurons in adolescent mice.

In B16J mice, our results show that morphine exposure during adolescence had no effect on levels of adult sociability or despair-like behaviour in the TS, with a modest effect in the FS. As already mentioned, our previous work indicated that abstinence from morphine exposure at the adult age produces a robust depressive-like syndrome, with increased behavioural despair and low sociability that can be prevented by chronic antidepressant treatment [24]. Together, our two studies suggest that adolescent Bl6J mice, when compared with adult mice, are less susceptible to morphine-induced emotional dysfunction. Interestingly, 
Hodgson et al recently reported that 3 days after chronic morphine exposure, adolescent but not adult C57BL/6 mice exhibit decreased immobility in the FS [23]. The authors interpreted decreased immobility during adolescent acute withdrawal as mood elation and suggested that "opioid withdrawal might affect mood differentially across ages". Within this line, beyond acute withdrawal, adolescence also associates with decreased sensitivity to long-term morphine-induced mood deregulation. Therefore, in adolescent mice, decreased severity of withdrawal, already reported for other drugs of abuse (see [90] for a review), may contribute to decreased effects of prolonged abstinence.

Pharmakokinetic differences between adolescent and adult Bl6J mice might account for such age-related differences in morphine effects. However, this hypothesis is unlikely, as a recent report has shown that upon systemic injection (i.p.; $17,8 \mathrm{mg} / \mathrm{kg}$ [91]) morphine achieves comparable plasma and brain levels from adolescence to adulthood. Alternatively, we suggest that the pharmacodynamic properties of morphine may vary during the lifespan. Adolescent and adult Bl6J mice may show different levels of expression or functional activities of the mu opioid receptor, whereby chronic exogenous mu receptor activation may lead to long-term depressive-like deficits in adult mice only. The mu receptor shows during rat development dynamic region-specific patterns of expression. After birth, expression of the mu receptor slowly declines during at least 24 months in the pituitary gland [92], while rapidly increasing in the hippocampus [93] and the striatum [94], two structures regulating emotions. Ontogenic variations have also been reported in MOR regulation of monoamine release [95], activity of the HPA axis [96] and prolactin secretion [97]. In mice, two early studies suggested that the expression of the mu opioid receptor globally increases during post-natal development in the whole brain $[98,99]$. Additional studies will be required to correlate developmental behavioural adaptations and post-natal regulation of mu receptor expression and function in brain regions regulating emotional-like behaviours.

\section{Conclusion}

In conclusion we show that, as for adult mice, morphine exposure in adolescent mice increases behavioural despair after prolonged abstinence, providing an animal model for comorbidity between opiate addiction and depression throughout the animal lifespan. We also show that, in contrast to adult mice, morphine treatment during adolescence enhances sociability in adulthood. Additional research will be required to understand where and how morphine acts during brain maturation to affect in the long-term emotional and social behaviours.

\section{Acknowledgments}

We thank Katia Befort for critical reading of the manuscript. This work was supported by the Centre National de la Recherche Scientifique (CNRS), Institut National de la Santé et de la Recherche Médicale (INSERM), and Université de Strasbourg (UdS). We thank also the Mouse Clinical Institute (ICS, Illkirch France), the European Union (Grant No.GENADDICT/FP6 005166), the Fondation pour la Recherche Médicale and the Fondation Fyssen (PE Lutz fellowships), and the National Institutes of Health (Grant NIAAA AA-16658 and NIDA DA-16768) for financial support.

\section{References}

1. Baler RD, Volkow ND. Drug addiction: the neurobiology of disrupted self-control. Trends Mol Med. 2006; 12:559-66. [PubMed: 17070107]

2. Koob GF, Le Moal M. Review. Neurobiological mechanisms for opponent motivational processes in addiction. Philos Trans R Soc Lond B Biol Sci. 2008; 363:3113-23. [PubMed: 18653439]

3. Grant BF, Stinson FS, Dawson DA, Chou SP, Dufour MC, Compton W, et al. Prevalence and cooccurrence of substance use disorders and independent mood and anxiety disorders: results from the 
National Epidemiologic Survey on Alcohol and Related Conditions. Archives of general psychiatry. 2004; 61:807-16. [PubMed: 15289279]

4. Kessler RC, Berglund P, Demler O, Jin R, Koretz D, Merikangas KR, et al. The epidemiology of major depressive disorder: results from the National Comorbidity Survey Replication (NCS-R). JAMA. 2003; 289:3095-105. [PubMed: 12813115]

5. Kessler RC, Berglund P, Demler O, Jin R, Merikangas KR, Walters EE. Lifetime prevalence and age-of-onset distributions of DSM-IV disorders in the National Comorbidity Survey Replication. Archives of general psychiatry. 2005; 62:593-602. [PubMed: 15939837]

6. Regier DA, Farmer ME, Rae DS, Locke BZ, Keith SJ, Judd LL, et al. Comorbidity of mental disorders with alcohol and other drug abuse. Results from the Epidemiologic Catchment Area (ECA) Study. JAMA. 1990; 264:2511-8. [PubMed: 2232018]

7. Grella CE, Karno MP, Warda US, Niv N, Moore AA. Gender and comorbidity among individuals with opioid use disorders in the NESARC study. Addictive behaviors. 2009; 34:498-504. [PubMed: 19232832]

8. Brewer DD, Catalano RF, Haggerty K, Gainey RR, Fleming CB. A meta-analysis of predictors of continued drug use during and after treatment for opiate addiction. Addiction. 1998; 93:73-92. [PubMed: 9624713]

9. Childress AR, Ehrman R, McLellan AT, MacRae J, Natale M, O’Brien CP. Can induced moods trigger drug-related responses in opiate abuse patients? J Subst Abuse Treat. 1994; 11:17-23. [PubMed: 8201629]

10. Rounsaville BJ, Kosten TR, Weissman MM, Kleber HD. Prognostic significance of psychopathology in treated opiate addicts. A 2.5-year follow-up study. Archives of general psychiatry. 1986; 43:739-45. [PubMed: 3729668]

11. Goudemand, M. Les états dépressifs. Lavoisier: Médecine Sciences Publications; 2010.

12. Aston-Jones G, Harris GC. Review - Brain substrates for increased drug seeking during protracted withdrawal. Neuropharmacology. 2004; 47(Suppl 1):167-79. [PubMed: 15464135]

13. Sakoori K, Murphy NP. Maintenance of conditioned place preferences and aversion in C57BL6 mice: effects of repeated and drug state testing. Behav Brain Res. 2005; 160:34-43. [PubMed: 15836898]

14. Wikler A, Pescor FT. Persistence of "relapse-tendencies" of rats previously made physically dependent on morphine. Psychopharmacologia. 1970; 16:375-84. [PubMed: 5461670]

15. Harris GC, Aston-Jones G. Altered motivation and learning following opiate withdrawal: evidence for prolonged dysregulation of reward processing. Neuropsychopharmacology : official publication of the American College of Neuropsychopharmacology. 2003; 28:865-71. [PubMed: 12736632]

16. Lieblich I, Yirmiya R, Liebeskind JC. Intake of and preference for sweet solutions are attenuated in morphine-withdrawn rats. Behavioral neuroscience. 1991; 105:965-70. [PubMed: 1663765]

17. Zhang D, Zhou X, Wang X, Xiang X, Chen H, Hao W. Morphine withdrawal decreases responding reinforced by sucrose self-administration in progressive ratio. Addiction biology. 2007; 12:152-7. [PubMed: 17508986]

18. Cooper ZD, Shi YG, Woods JH. Reinforcer-dependent enhancement of operant responding in opioid-withdrawn rats. Psychopharmacology. 2010; 212:369-78. [PubMed: 20686752]

19. Rouibi K, Contarino A. Increased motivation to eat in opiate-withdrawn mice. Psychopharmacology. 2011

20. Anraku T, Ikegaya Y, Matsuki N, Nishiyama N. Withdrawal from chronic morphine administration causes prolonged enhancement of immobility in rat forced swimming test. Psychopharmacology. 2001; 157:217-20. [PubMed: 11594449]

21. Molina VA, Heyser CJ, Spear LP. Chronic variable stress or chronic morphine facilitates immobility in a forced swim test: reversal by naloxone. Psychopharmacology. 1994; 114:433-40. [PubMed: 7855201]

22. Grasing K, Ghosh S. Selegiline prevents long-term changes in dopamine efflux and stress immobility during the second and third weeks of abstinence following opiate withdrawal. Neuropharmacology. 1998; 37:1007-17. [PubMed: 9833630] 
23. Hodgson SR, Hofford RS, Wellman PJ, Eitan S. Different affective response to opioid withdrawal in adolescent and adult mice. Life Sci. 2009; 84:52-60. [PubMed: 19032959]

24. Goeldner C, Lutz PE, Darcq E, Halter T, Clesse D, Ouagazzal AM, et al. Impaired emotional-like behavior and serotonergic function during protracted abstinence from chronic morphine. Biological psychiatry. 2011; 69:236-44. [PubMed: 20947067]

25. Paus T, Keshavan M, Giedd JN. Why do many psychiatric disorders emerge during adolescence? Nat Rev Neurosci. 2008; 9:947-57. [PubMed: 19002191]

26. Romeo RD. Adolescence: a central event in shaping stress reactivity. Dev Psychobiol. 2010; 52:244-53. [PubMed: 20175102]

27. Spear LP. The adolescent brain and age-related behavioral manifestations. Neuroscience and biobehavioral reviews. 2000; 24:417-63. [PubMed: 10817843]

28. Romeo RD. Pubertal maturation and programming of hypothalamic-pituitary-adrenal reactivity. Front Neuroendocrinol. 2010; 31:232-40. [PubMed: 20193707]

29. Degenhardt L, Coffey C, Moran P, Carlin JB, Patton GC. The predictors and consequences of adolescent amphetamine use: findings from the Victoria Adolescent Health Cohort Study. Addiction. 2007; 102:1076-84. [PubMed: 17567396]

30. Hayatbakhsh MR, Najman JM, Jamrozik K, Mamun AA, Alati R, Bor W. Cannabis and anxiety and depression in young adults: a large prospective study. J Am Acad Child Adolesc Psychiatry. 2007; 46:408-17. [PubMed: 17314727]

31. Rao U, Daley SE, Hammen C. Relationship between depression and substance use disorders in adolescent women during the transition to adulthood. J Am Acad Child Adolesc Psychiatry. 2000; 39:215-22. [PubMed: 10673833]

32. Doherty J, Ogbomnwan Y, Williams B, Frantz K. Age-dependent morphine intake and cueinduced reinstatement, but not escalation in intake, by adolescent and adult male rats. Pharmacol Biochem Behav. 2009; 92:164-72. [PubMed: 19091300]

33. Zhang Y, Picetti R, Butelman ER, Schlussman SD, Ho A, Kreek MJ. Behavioral and neurochemical changes induced by oxycodone differ between adolescent and adult mice. Neuropsychopharmacology : official publication of the American College of Neuropsychopharmacology. 2009; 34:912-22. [PubMed: 18784649]

34. Doherty JM, Frantz KJ. Heroin self-administration and reinstatement of heroin-seeking in adolescent vs. adult male rats. Psychopharmacology. 2011

35. Somerville LH, Jones RM, Casey BJ. A time of change: behavioral and neural correlates of adolescent sensitivity to appetitive and aversive environmental cues. Brain Cogn. 2009; 72:12433. [PubMed: 19695759]

36. Yurgelun-Todd D. Emotional and cognitive changes during adolescence. Curr Opin Neurobiol. 2007; 17:251-7. [PubMed: 17383865]

37. Matthes HW, Maldonado R, Simonin F, Valverde O, Slowe S, Kitchen I, et al. Loss of morphineinduced analgesia, reward effect and withdrawal symptoms in mice lacking the mu-opioid-receptor gene. Nature. 1996; 383:819-23. [PubMed: 8893006]

38. American Psychiatric Association. Diagnostic and statistical manual of mental disorders. 4. Washington, DC: American Psychiatric Association; 1994.

39. Goeldner C, Reiss D, Kieffer BL, Ouagazzal AM. Endogenous nociceptin/orphanin-FQ in the dorsal hippocampus facilitates despair-related behavior. Hippocampus. 2010; 20:911-6. [PubMed: 20087887]

40. Wall PM, Blanchard RJ, Yang M, Blanchard DC. Infralimbic D2 receptor influences on anxietylike behavior and active memory/attention in CD-1 mice. Prog Neuropsychopharmacol Biol Psychiatry. 2003; 27:395-410. [PubMed: 12691774]

41. Mandillo S, Tucci V, Holter SM, Meziane H, Banchaabouchi MA, Kallnik M, et al. Reliability, robustness, and reproducibility in mouse behavioral phenotyping: a cross-laboratory study. Physiol Genomics. 2008; 34:243-55. [PubMed: 18505770]

42. Belzung C, Le Guisquet AM, Crestani F. Flumazenil induces benzodiazepine partial agonist-like effects in BALB/c but not C57BL/6 mice. Psychopharmacology. 2000; 148:24-32. [PubMed: $10663414]$ 
43. Akillioglu K, Melik EB, Melik E, Boga A. Effect of ketamine on exploratory behaviour in BALB/ C and C57BL/6 mice. Pharmacol Biochem Behav. 2012; 100:513-7. [PubMed: 22037409]

44. Tang X, Orchard SM, Sanford LD. Home cage activity and behavioral performance in inbred and hybrid mice. Behav Brain Res. 2002; 136:555-69. [PubMed: 12429418]

45. Bothe GW, Bolivar VJ, Vedder MJ, Geistfeld JG. Genetic and behavioral differences among five inbred mouse strains commonly used in the production of transgenic and knockout mice. Genes Brain Behav. 2004; 3:149-57. [PubMed: 15140010]

46. Carola V, D’Olimpio F, Brunamonti E, Mangia F, Renzi P. Evaluation of the elevated plus-maze and open-field tests for the assessment of anxiety-related behaviour in inbred mice. Behav Brain Res. 2002; 134:49-57. [PubMed: 12191791]

47. Hughes RN. The value of spontaneous alternation behavior (SAB) as a test of retention in pharmacological investigations of memory. Neuroscience and biobehavioral reviews. 2004; 28:497-505. [PubMed: 15465137]

48. Kendler KS, Prescott CA, Myers J, Neale MC. The structure of genetic and environmental risk factors for common psychiatric and substance use disorders in men and women. Archives of general psychiatry. 2003; 60:929-37. [PubMed: 12963675]

49. Goldman D, Oroszi G, Ducci F. The genetics of addictions: uncovering the genes. Nat Rev Genet. 2005; 6:521-32. [PubMed: 15995696]

50. Caspi A, Sugden K, Moffitt TE, Taylor A, Craig IW, Harrington H, et al. Influence of life stress on depression: moderation by a polymorphism in the 5-HTT gene. Science. 2003; 301:386-9. [PubMed: 12869766]

51. Pothion S, Bizot JC, Trovero F, Belzung C. Strain differences in sucrose preference and in the consequences of unpredictable chronic mild stress. Behav Brain Res. 2004; 155:135-46. [PubMed: 15325787]

52. Zhang X, Beaulieu JM, Sotnikova TD, Gainetdinov RR, Caron MG. Tryptophan hydroxylase-2 controls brain serotonin synthesis. Science. 2004; 305:217. [PubMed: 15247473]

53. Kest B, Palmese CA, Hopkins E, Adler M, Juni A, Mogil JS. Naloxone-precipitated withdrawal jumping in 11 inbred mouse strains: evidence for common genetic mechanisms in acute and chronic morphine physical dependence. Neuroscience. 2002; 115:463-9. [PubMed: 12421612]

54. Klein G, Juni A, Waxman AR, Arout CA, Inturrisi CE, Kest B. A survey of acute and chronic heroin dependence in ten inbred mouse strains: evidence of genetic correlation with morphine dependence. Pharmacol Biochem Behav. 2008; 90:447-52. [PubMed: 18472145]

55. Szumlinski KK, Lominac KD, Frys KA, Middaugh LD. Genetic variation in heroin-induced changes in behaviour: effects of B6 strain dose on conditioned reward and locomotor sensitization in 129-B6 hybrid mice. Genes Brain Behav. 2005; 4:324-36. [PubMed: 16011579]

56. Belzung C, Barreau S. Differences in drug-induced place conditioning between BALB/c and C57B1/6 mice. Pharmacol Biochem Behav. 2000; 65:419-23. [PubMed: 10683481]

57. Bodnar RJ. Endogenous opiates and behavior: 2010. Peptides. 2011; 32:2522-52. [PubMed: 21983105]

58. Matsuo N, Takao K, Nakanishi K, Yamasaki N, Tanda K, Miyakawa T. Behavioral profiles of three C57BL/6 substrains. Front Behav Neurosci. 2010; 4:29. [PubMed: 20676234]

59. Cryan JF, Holmes A. The ascent of mouse: advances in modelling human depression and anxiety. Nat Rev Drug Discov. 2005; 4:775-90. [PubMed: 16138108]

60. File SE. Animal models of different anxiety states. Advances in biochemical psychopharmacology. 1995; 48:93-113. [PubMed: 7653328]

61. Rodgers RJ. Animal models of 'anxiety': where next? Behavioural pharmacology. 1997; 8:477-96. discussion 97-504. [PubMed: 9832964]

62. Sankoorikal GM, Kaercher KA, Boon CJ, Lee JK, Brodkin ES. A mouse model system for genetic analysis of sociability: C57BL/6J versus BALB/cJ inbred mouse strains. Biological psychiatry. 2006; 59:415-23. [PubMed: 16199013]

63. Moy SS, Nadler JJ, Young NB, Perez A, Holloway LP, Barbaro RP, et al. Mouse behavioral tasks relevant to autism: phenotypes of 10 inbred strains. Behav Brain Res. 2007; 176:4-20. [PubMed: 16971002] 
64. Dulawa SC, Holick KA, Gundersen B, Hen R. Effects of chronic fluoxetine in animal models of anxiety and depression. Neuropsychopharmacology : official publication of the American College of Neuropsychopharmacology. 2004; 29:1321-30. [PubMed: 15085085]

65. Liu X, Gershenfeld HK. Genetic differences in the tail-suspension test and its relationship to imipramine response among 11 inbred strains of mice. Biological psychiatry. 2001; 49:575-81. [PubMed: 11297714]

66. Norcross M, Mathur P, Enoch AJ, Karlsson RM, Brigman JL, Cameron HA, et al. Effects of adolescent fluoxetine treatment on fear-, anxiety- or stress-related behaviors in C57BL/6J or BALB/cJ mice. Psychopharmacology. 2008; 200:413-24. [PubMed: 18594797]

67. Buckman SG, Hodgson SR, Hofford RS, Eitan S. Increased elevated plus maze open-arm time in mice during spontaneous morphine withdrawal. Behav Brain Res. 2009; 197:454-6. [PubMed: 18955087]

68. Harris GC, Aston-Jones G. Augmented accumbal serotonin levels decrease the preference for a morphine associated environment during withdrawal. Neuropsychopharmacology : official publication of the American College of Neuropsychopharmacology. 2001; 24:75-85. [PubMed: 11106878]

69. Grasing K, Wang A, Schlussman S. Behavioral measures of anxiety during opiate withdrawal. Behav Brain Res. 1996; 80:195-201. [PubMed: 8905143]

70. Lundqvist T. Cognitive consequences of cannabis use: comparison with abuse of stimulants and heroin with regard to attention, memory and executive functions. Pharmacol Biochem Behav. 2005; 81:319-30. [PubMed: 15925403]

71. Fishbein DH, Krupitsky E, Flannery BA, Langevin DJ, Bobashev G, Verbitskaya E, et al. Neurocognitive characterizations of Russian heroin addicts without a significant history of other drug use. Drug and alcohol dependence. 2007; 90:25-38. [PubMed: 17382488]

72. Itoh J, Ukai M, Kameyama T. Dynorphin A-(1-13) potently improves the impairment of spontaneous alternation performance induced by the mu-selective opioid receptor agonist DAMGO in mice. J Pharmacol Exp Ther. 1994; 269:15-21. [PubMed: 7909556]

73. Ma MX, Chen YM, He J, Zeng T, Wang JH. Effects of morphine and its withdrawal on Y-maze spatial recognition memory in mice. Neuroscience. 2007; 147:1059-65. [PubMed: 17601672]

74. Talley CP, Arankowsky-Sandoval G, McCarty R, Gold PE. Attenuation of morphine-induced behavioral changes in rodents by D- and L-glucose. Neurobiol Learn Mem. 1999; 71:62-79. [PubMed: 9889073]

75. Ukai M, Watanabe Y, Kameyama T. Effects of endomorphins-1 and -2, endogenous mu-opioid receptor agonists, on spontaneous alternation performance in mice. European journal of pharmacology. 2000; 395:211-5. [PubMed: 10812051]

76. Moles A, Kieffer BL, D' Amato FR. Deficit in attachment behavior in mice lacking the mu-opioid receptor gene. Science. 2004; 304:1983-6. [PubMed: 15218152]

77. Barr CS, Schwandt ML, Lindell SG, Higley JD, Maestripieri D, Goldman D, et al. Variation at the mu-opioid receptor gene (OPRM1) influences attachment behavior in infant primates. Proceedings of the National Academy of Sciences of the United States of America. 2008; 105:5277-81. [PubMed: 18378897]

78. Copeland WE, Sun H, Costello EJ, Angold A, Heilig MA, Barr CS. Child mu-opioid receptor gene variant influences parent-child relations. Neuropsychopharmacology : official publication of the American College of Neuropsychopharmacology. 2011; 36:1165-70. [PubMed: 21326192]

79. Ladd GW. Peer relationships and social competence during early and middle childhood. Annu Rev Psychol. 1999; 50:333-59. [PubMed: 10074682]

80. Depue RA, Morrone-Strupinsky JV. A neurobehavioral model of affiliative bonding: implications for conceptualizing a human trait of affiliation. Behav Brain Sci. 2005; 28:313-50. discussion 50 95. [PubMed: 16209725]

81. Van den Berg CL, Kitchen I, Gerrits MA, Spruijt BM, Van Ree JM. Morphine treatment during juvenile isolation increases social activity and opioid peptides release in the adult rat. Brain research. 1999; 830:16-23. [PubMed: 10350555]

82. Trezza V, Baarendse PJ, Vanderschuren LJ. The pleasures of play: pharmacological insights into social reward mechanisms. Trends Pharmacol Sci. 2010; 31:463-9. [PubMed: 20684996] 
83. Panksepp JB, Lahvis GP. Social reward among juvenile mice. Genes Brain Behav. 2007; 6:66171. [PubMed: 17212648]

84. Panksepp JB, Wong JC, Kennedy BC, Lahvis GP. Differential entrainment of a social rhythm in adolescent mice. Behav Brain Res. 2008; 195:239-45. [PubMed: 18840476]

85. Trezza V, Damsteegt R, Achterberg EJ, Vanderschuren LJ. Nucleus Accumbens \{micro\}-Opioid Receptors Mediate Social Reward. The Journal of neuroscience : the official journal of the Society for Neuroscience. 2011; 31:6362-70. [PubMed: 21525276]

86. Meyer-Lindenberg A, Domes G, Kirsch P, Heinrichs M. Oxytocin and vasopressin in the human brain: social neuropeptides for translational medicine. Nat Rev Neurosci. 2011; 12:524-38. [PubMed: 21852800]

87. Morris MS, Domino EF, Domino SE. Opioid modulation of oxytocin release. J Clin Pharmacol. 2010; 50:1112-7. [PubMed: 20350953]

88. Honda K, Takano Y. New topics in vasopressin receptors and approach to novel drugs: involvement of vasopressin $\mathrm{V} 1 \mathrm{a}$ and $\mathrm{V} 1 \mathrm{~b}$ receptors in nociceptive responses and morphineinduced effects. J Pharmacol Sci. 2009; 109:38-43. [PubMed: 19151540]

89. Lutz PE, Pradhan AA, Goeldner C, Kieffer BL. Sequential and opposing alterations of 5-HT(1A) receptor function during withdrawal from chronic morphine. Eur Neuropsychopharmacol. 2011 in press.

90. Schramm-Sapyta NL, Walker QD, Caster JM, Levin ED, Kuhn CM. Are adolescents more vulnerable to drug addiction than adults? Evidence from animal models. Psychopharmacology. 2009; 206:1-21. [PubMed: 19547960]

91. Koek W, France CP, Javors MA. Morphine-induced motor stimulation, motor incoordination, and hypothermia in adolescent and adult mice. Psychopharmacology. 2012; 219:1027-37. [PubMed: 21837433]

92. Carretero J, Bodego P, Rodriguez RE, Rubio M, Blanco E, Burks DJ. Expression of the mu-opioid receptor in the anterior pituitary gland is influenced by age and sex. Neuropeptides. 2004; 38:638. [PubMed: 15223267]

93. Gazyakan E, Disko U, Haaf A, Heimrich B, Jackisch R. Postnatal development of opioid receptors modulating acetylcholine release in hippocampus and septum of the rat. Brain research Developmental brain research. 2000; 123:135-41. [PubMed: 11042342]

94. Talbot JN, Happe HK, Murrin LC. Mu opioid receptor coupling to Gi/o proteins increases during postnatal development in rat brain. J Pharmacol Exp Ther. 2005; 314:596-602. [PubMed: 15860573]

95. De Vries TJ, Hogenboom F, Mulder AH, Schoffelmeer AN. Ontogeny of mu-, delta- and kappaopioid receptors mediating inhibition of neurotransmitter release and adenylate cyclase activity in rat brain. Brain research Developmental brain research. 1990; 54:63-9. [PubMed: 2163782]

96. Adamson WT, Windh RT, Blackford S, Kuhn CM. Ontogeny of mu- and kappa-opiate receptor control of the hypothalamo-pituitary-adrenal axis in rats. Endocrinology. 1991; 129:959-64. [PubMed: 1649751]

97. Blackford SP, Little PJ, Kuhn CM. Mu- and kappa-opiate receptor control of prolactin secretion in rats: ontogeny and interaction with serotonin. Endocrinology. 1992; 131:2891-7. [PubMed: 1332851]

98. Tavani A, Robson LE, Kosterlitz HW. Differential postnatal development of mu-, delta-and chiopioid binding sites in mouse brain. Brain research. 1985; 355:306-9. [PubMed: 3002543]

99. Barg J, Rius RA, Bem WT, Belcheva MM, Loh YP, Coscia CJ. Differential development of betaendorphin and mu opioid binding sites in mouse brain. Brain research Developmental brain research. 1992; 66:71-6. [PubMed: 1318173] 


\section{Research Highlights}

- Chronic morphine treatment in adolescent mice does not affect anxiety-like responses into adulthood

- Chronic morphine treatment in adolescent mice increases despair-like behaviour into adulthood

- Chronic morphine treatment in adolescent mice strain-dependently enhances sociability into adulthood 
A) 6-day morphine treatment (20-

$100 \mathrm{mg} / \mathrm{kg})$

\author{
Behavior \\ LD, OF, SI, TS, FS, YM
}

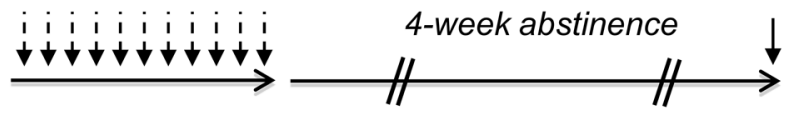

B)

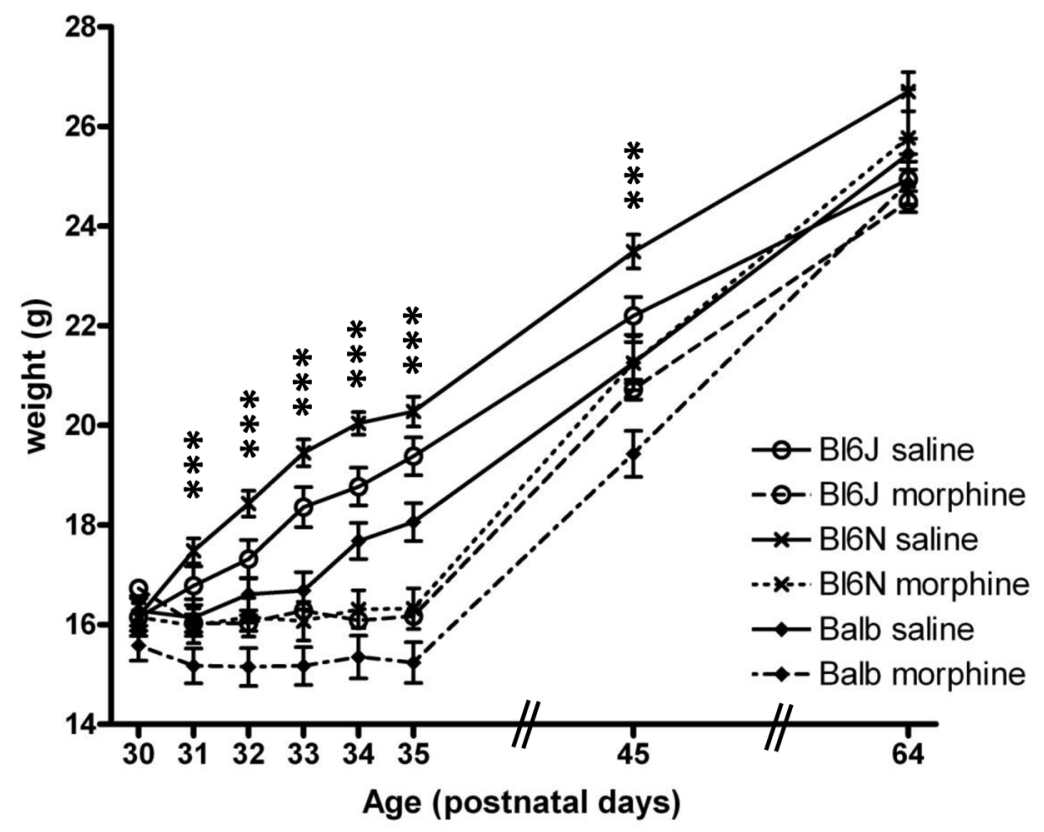

Figure 1.

(A) Experimental timeline. (B) Weight evolution during chronic morphine treatment and 4week abstinence. C57BL/J6 (B16J), C57BL/6N (B16N) and Balb/cByJ (Balb) mice received chronic injections with increasing morphine doses $(20-100 \mathrm{mg} / \mathrm{kg}$, i.p., twice daily), or saline ( $\mathrm{n}=12 \mathrm{mice} / \mathrm{group} / \mathrm{strain}$ ), during 6 days, from post-natal day 30 (P30) to P35. After 4 weeks of abstinence, behavioural responses were assessed in the following order: light-dark (LD), open-field (OF), social interactions (SI), tail suspension (TS), forced swim (FS) and Y-maze (YM) tests. As an index of general opiate effects, mice were weighed daily during chronic injections and after 10 (P45) and 29 (P64) days of abstinence. Morphine-treated mice showed significantly decreased body weights compared to saline controls from P31 to P45. Balb mice showed lowest weight across the experiment (see text). Data are mean \pm s.e.m. $* * * \mathrm{p}<0.001$, ANOVA main effect of morphine treatment. 
A)

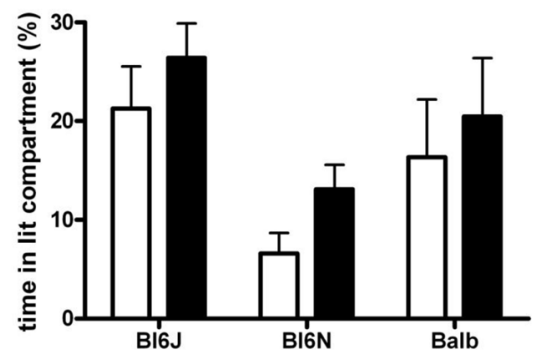

C)

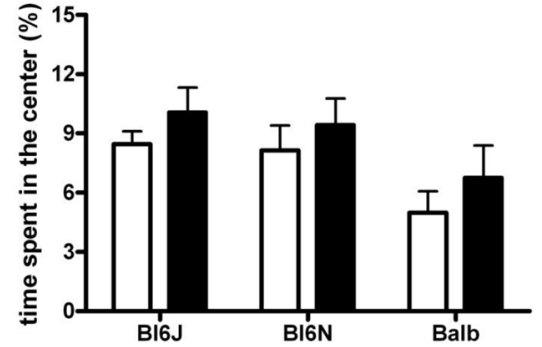

B)

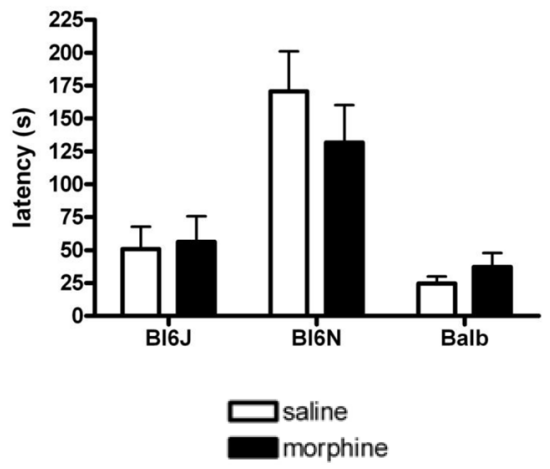

D)

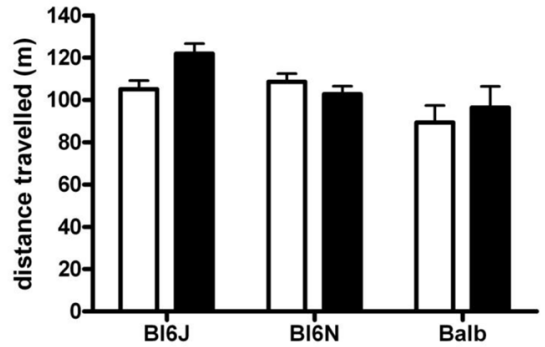

Figure 2. Chronic morphine treatment during adolescence does not affect anxiety-like responses and locomotor activity in adulthood

4 weeks after the last morphine or saline injection ( $n=12$ mice/group/strain), we assessed behavioural responses in C57BL/J6 (B16J), C57BL/6N (B16N) and Balb/cByJ (Balb) mice. Morphine abstinence had no effect on anxiety-like behaviours in the Light-Dark (A, B) and the Open-Field $(\mathbf{C})$, or on locomotor activity in the Open-Field (D). Significant effects of strain are not depicted (see text). Data are mean \pm s.e.m. 
Social interactions
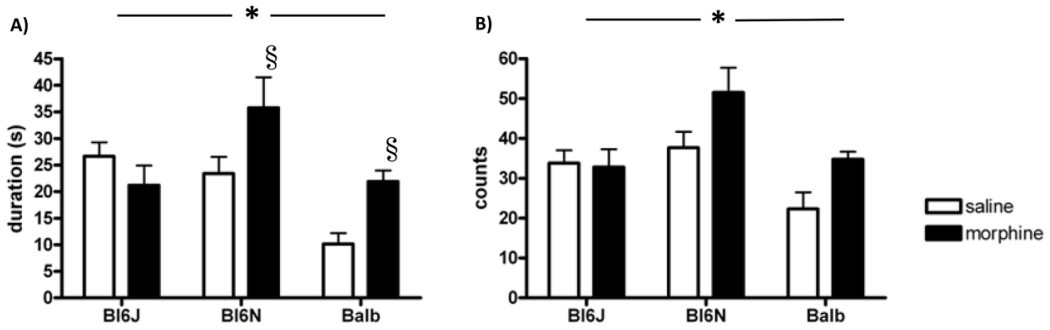

Figure 3. Chronic morphine treatment during adolescence increases social behaviours in adulthood

4 weeks after the last morphine or saline injection ( $\mathrm{n}=12 \mathrm{mice} / \mathrm{group} / \mathrm{strain})$, we assessed social interactions in C57BL/6J (B16J), C57BL/6N (B16N) and Balb/cByJ (Balb) mice.

Morphine abstinence increased the number of occurrences $(\mathbf{A})$ and the total duration $(\mathbf{B})$ of social behaviours in B16N and Balb mice, but not in B16J. Significant effects of strain are not depicted (see text). Data are mean \pm s.e.m. *p<0.05, ANOVA main effect of morphine abstinence; $\S p<0.05$, post-hoc comparisons for the effect of morphine abstinence in each strain. 


\section{Tail suspension}
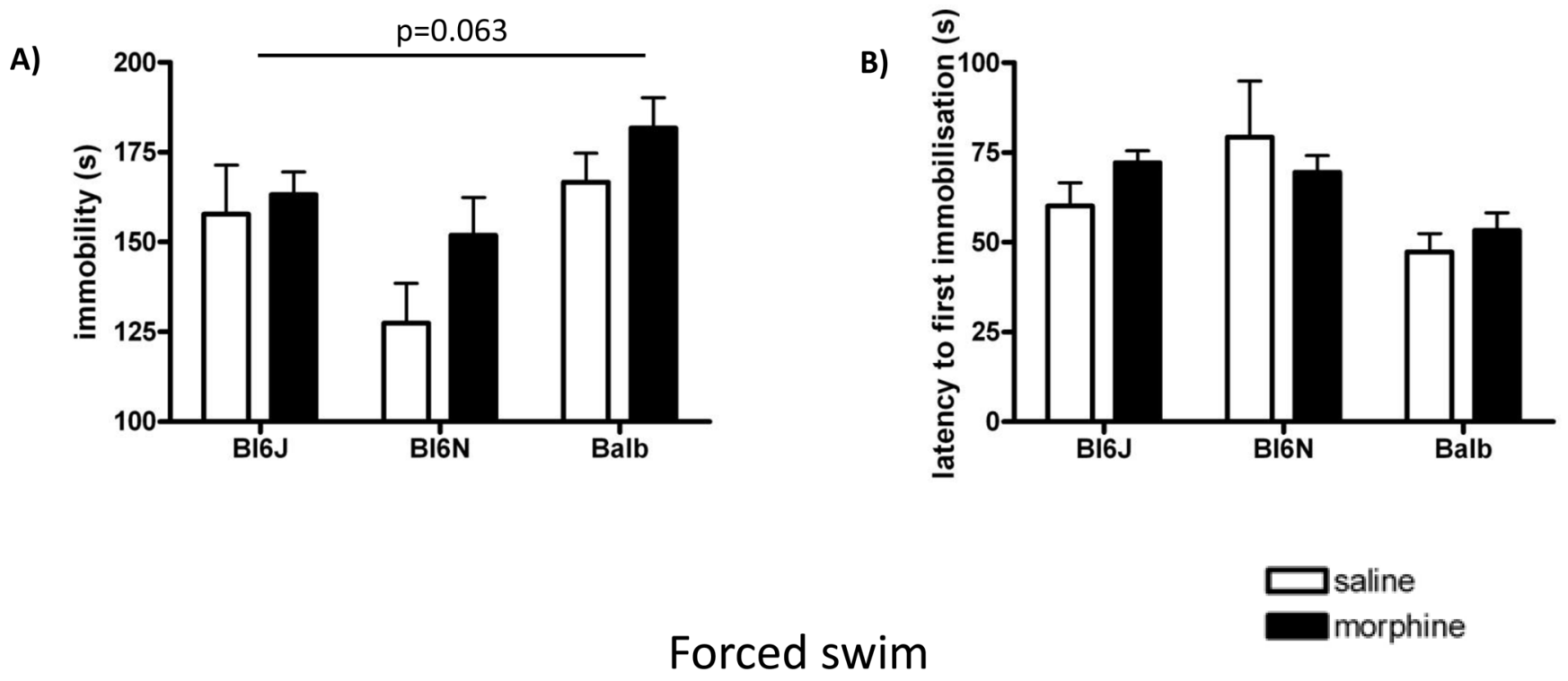

C)

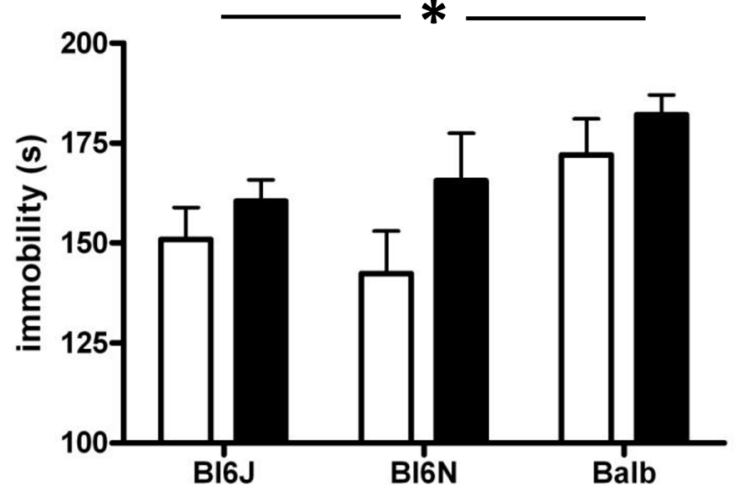

D)

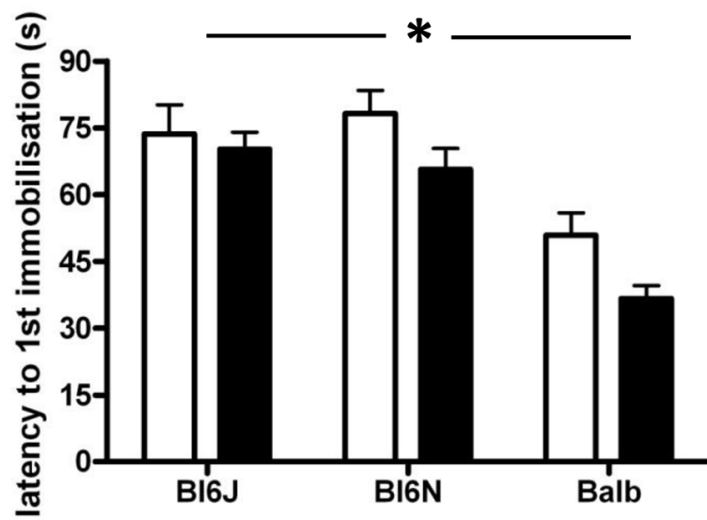

Figure 4. Chronic morphine treatment during adolescence increases despair-like behaviours in adulthood

4 weeks after the last morphine or saline injection ( $\mathrm{n}=12 \mathrm{mice} / \mathrm{group} / \mathrm{strain})$, we assessed behavioural responses in tail suspension and forced swim tests of C57BL/6J (B16J), C57BL/ $6 \mathrm{~N}(\mathrm{Bl6N})$ and Balb/cByJ (Balb) mice. Time spent immobile (A and C) and latency to first immobilization (B and $\mathbf{D}$ ) are represented. Morphine abstinence increased despair-like behaviours in the forced swim (immobility and latency to first immobilization, $\mathbf{C}$ and $\mathbf{D}$ ), and this effect was almost significant in the tail suspension (immobility duration, $\mathbf{A}$ ). Significant effects of strain are not depicted (see text). Data are mean \pm s.e.m. ${ }^{*} p<0.05$, ANOVA main effect of morphine abstinence. 


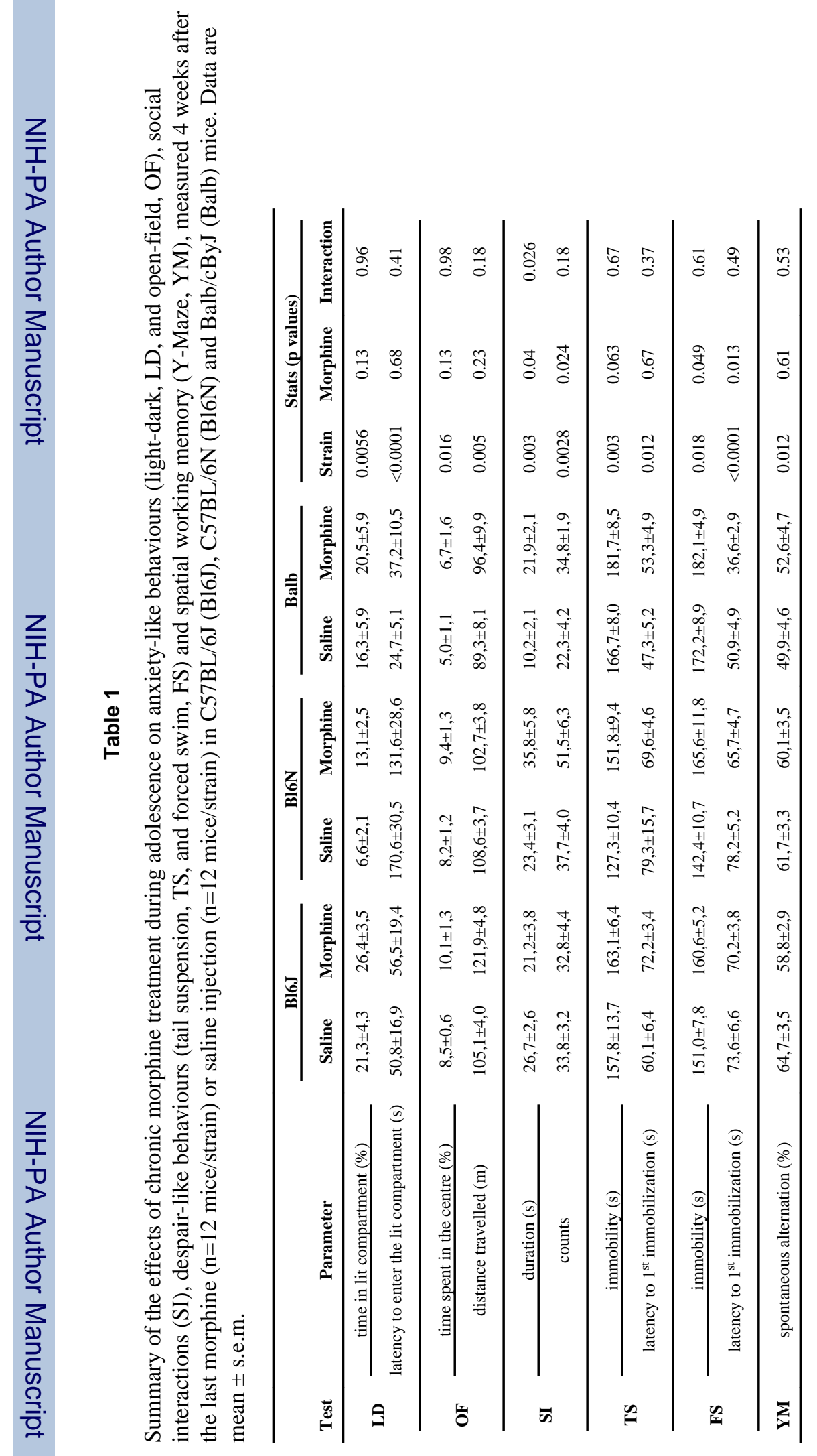

